$\begin{array}{ll} & \text { Etnográfica } \\ \text { etnográfica } & \text { Revista do Centro em Rede de Investigação em }\end{array}$

Antropologia

vol. $16(3) \mid 2012$

Vol. $16(3)$

\title{
Como nos tornamos antropólogos? Imprevisto e mutualidade na constituição do terreno etnográfico da saúde mental em Lisboa
}

How do we become anthropologists? Unexpectedness and mutuality in the fieldwork of mental health in Lisbon

\section{Madalena Patriarca}

\section{(2) OpenEdition}

\section{Journals}

\section{Edição electrónica}

URL: https://journals.openedition.org/etnografica/2130

DOI: 10.4000/etnografica.2130

ISSN: 2182-2891

\section{Editora}

Centro em Rede de Investigação em Antropologia

\section{Edição impressa}

Data de publição: 1 outubro 2012

Paginação: 589-618

ISSN: 0873-6561

\section{Refêrencia eletrónica}

Madalena Patriarca, «Como nos tornamos antropólogos? Imprevisto e mutualidade na constituição do terreno etnográfico da saúde mental em Lisboa», Etnográfica [Online], vol. 16 (3) | 2012, posto online no dia 08 outubro 2012, consultado o 12 fevereiro 2022. URL: http://journals.openedition.org/ etnografica/2130 ; DOI: https://doi.org/10.4000/etnografica.2130

\section{(c) (†) 8}

Etnográfica is licensed under a Creative Commons Attribution-NonCommercial 4.0 International License. 


\section{Como nos tornamos antropólogos? Imprevisto e mutualidade} na constituição do terreno etnográfico da saúde mental em Lisboa

\section{Madalena Patriarca}

Este artigo trata da necessidade de o antropólogo integrar os imponderáveis do terreno na descrição etnográfica enquanto condição de produção de conhecimento antropológico. Ao longo do trabalho de campo que realizou em Lisboa e visava compreender como os psiquiatras aprendiam a sua profissão, a autora foi sendo defrontada com entraves diversos à observação de alguns serviços psiquiátricos hospitalares. Foi ainda surpreendida pela desconfiança explícita de muitos psiquiatras quanto à possibilidade de a abordagem etnográfica conseguir traduzir "com fiabilidade científica" a identidade social deste grupo profissional. Porém, da incessante procura de novos lugares para observar, a par de uma reflexão constante sobre as dificuldades sentidas no trabalho de campo, a investigação resultou na descoberta inesperada, não de um serviço de psiquiatria, mas de toda uma cartografia histórico-psiquiátrica intimamente ligada com as dinâmicas do quotidiano da cidade. Recorrendo ao seu material etnográfico a autora repensa, assim, categorias como reflexividade, intersubjetividade e representação, e propõe-se encarar a pesquisa de campo como processo de aprendizagem do próprio antropólogo.

PALAVRAS-CHAVE: antropologia, etnografia, epistemologia, interação, psiquiatria.

How do we become anthropologists? Unexpectedness and mutuality in the fieldwork of mental health in Lisbon - Under what conditions can unexpectedness in the fieldwork become a way of anthropological knowing? How can we write about silence and the concealed? This paper explores unexpected situations that occurred during our fieldwork on several psychiatric hospital wards in the city. Due to their medical thinking most psychiatrists are suspicious of ethnographic data, mainly when they are the ones the anthropologist wants to study, serving as gatekeepers is a way to limit our access to their medical world. This becomes highly problematic since the ethnographer feels most of the time as having failed her fieldwork. But differently, our proposal is to understand fieldwork difficulties as a process of anthropological apprenticeship. In other words, difficulties in the fieldwork become paths to understand and to craft our knowledge of a shared world.

KEYWORDS: anthropology, ethnography, epistemology, interaction, psychiatry.

PATRIARCA, Madalena (madalena.rolim@sapo.pt) - Instituto de Ciências Sociais da Universidade de Lisboa, Portugal. 
INTRODUÇÃO:

\section{MUTUALIDADE E CONDIÇÃO DO CONHECIMENTO ANTROPOLÓGICO}

Este ensaio é uma reflexão sobre os imponderáveis com que me defrontei no meu trabalho de campo, realizado entre 2006 e 2010 , em diversas instituições e serviços de psiquiatria e saúde mental da Área Metropolitana de Lisboa. Esse trabalho tinha por objetivo inicial compreender como se tornam psiquiatras aqueles que se especializam nesta área da medicina.

Ao longo da investigação ocorreram imprevistos de ordem diversa que dificultaram a minha fixação num dado serviço para cuja observação tinha, muitas vezes, já obtido a devida autorização. Os procedimentos e as categorias que antecipadamente tinha imaginado como certos - a delimitação prévia do terreno ou a escolha da observação de um dado serviço hospitalar como "representativo" da realidade que pretendia observar - tiveram de ser, por conseguinte, inúmeras vezes repensados ante a constatação de que nenhum lugar é um "ali" previamente identificado e traduzido por uma proposição de tipo ontológico.

Quatro anos após o início do trabalho de campo, constatei que produzira um terreno etnográfico a partir do qual pudera compreender que as fronteiras do campo psiquiátrico se encontravam muito para além de qualquer serviço hospitalar que pudesse ter observado. Contudo, paradoxalmente, os imprevistos encontrados e as tentativas de resolução desses mesmos imprevistos permitiram-me compreender os processos de constituição identitária de psiquiatras também como processos de aprendizagem do "ser antropólogo".

Deste modo, os entraves encontrados converteram-se em conhecimento sobre toda uma cartografia psiquiátrica que inclui os hospitais, mas que também transpõe os seus limites físicos e simbólicos. São disso exemplos as memórias inscritas na disposição arquitetónica de hospitais no tecido urbano e a sua íntima relação, quer com as vanguardas científicas e arquitetónicas do seu tempo, quer com o complexo espaço político de planeamento e expansão geográfica da própria urbe; ou os itinerários que levam a que uns utentes tenham de se dirigir a determinados serviços locais de atendimento e outros a serviços em áreas geográficas diferentes, constituindo assim um outro mapa, local, regional e nacional, da saúde mental; ou ainda as acessibilidades da rede de cuidados continuados de saúde, que, por sua vez, se inscrevem numa dimensão mais ampla de integração da saúde numa utopia de desenvolvimento global e progresso típicos da modernidade tardia.

Mas do encontro com psiquiatras resultou a necessidade de encarar a mutualidade enquanto categoria de produção de conhecimento antropológico. Neste caso, esta necessidade resultou do facto de também eu ter sido, não somente observada pelos meus informantes, como ainda confrontada sobre os meus próprios processos de produção de conhecimento sobre eles. Foram mesmo inúmeras as situações em que senti a sua perplexidade ou a sua 
simpática condescendência quando me interrogavam sobre as hipóteses que eu levava para o terreno e eu tentava explicar-lhes que não tinha hipóteses, pelo menos, no sentido convencional, mas apenas problematizações. Mesmo assim, era confrontada ainda com certa curiosidade: como tencionava recolher os dados para análise? Com que metodologia? Como os iria representar? Porque escolhera psiquiatras e não outra realidade para observar?

A perplexidade era recíproca e devolvia-lhes uma curiosidade idêntica: como explicavam a aparente contradição da ação psiquiátrica que, se por um lado reclamava para si um procedimento profissional consentâneo com a objetividade científica, por outro justificava o "encontro" com o doente como instrumento privilegiado de acesso à pessoa humana? Então explicavam-me que a psiquiatria era uma ciência, por vezes, uma arte "especial". Não dispunha dos meios de diagnóstico disponíveis para as outras especialidades, mas isso não a tornava menos científica:

"As doenças mentais não se veem em hemogramas, nem em TAC. Tem de se aprender a detetá-las por outros meios. Por isso é que a interpretação correta dos sintomas do doente é tão importante. Por isso, demoramos muito mais tempo na consulta do que as outras especialidades da medicina, embora isto também já esteja a perder-se e a psiquiatria, certa psiquiatria, tenda a agir como se a dimensão humana não estivesse lá, e apenas estivesse a doença. Por isso, (ainda) privilegiamos tanto o face a face com o nosso doente, porque para termos acesso à doença precisamos da pessoa. E como é que temos esse acesso? Somos todos humanos, não é? Eu chamo-lhe intuição e digo-lhe que ela (a intuição) se aperfeiçoa com o tempo. Você há de chamar-lhe outra coisa qualquer na sua antropologia. O que é que lhe chama?"

Ao mesmo tempo, este esforço para justificarem a sua ambivalência metodológica mostrava-me que lhes parecia, apesar de tudo, que eu conseguiria compreender o seu mundo e também que valorizavam a representação que eu viesse a fazer deles. Em alguns psiquiatras encontrei até um outro tipo de interlocução, uma vontade de colaboração conjunta na representação do grupo, embora sempre nos moldes que julgavam poder ser de interesse comum face aos seus próprios interesses de representação médico-profissional.

As implicações desta intersubjetividade em campo levaram-me então a pensar esta última como uma dimensão da interlocução - uma mutualidade -, porém, aqui bem distinta da metáfora da tradução, regida sobretudo por categorias de representação de natureza linguística, ou até mesmo de uma metáfora da reciprocidade simétrica, no sentido latouriano.

Mas como redefinir então a investigação face aos imponderáveis que se nos deparam a cada passo na pesquisa de campo e que fazem com que o antropólogo sinta, não poucas vezes, que as relações de poder estabelecidas em campo 
lhe são frequente e amplamente desfavoráveis, apesar do mundo comum partilhado?

Cabe aqui esclarecer que uso a expressão "um mundo comum partilhado", no sentido que lhe conferem Christina Toren e João de Pina-Cabral (2009). Para estes antropólogos, alteridade e identidade não deverão ser encaradas como simétricas, pois a possibilidade de diferenciação e de identificação impõe-se historicamente, quer dizer, impõe-se sob a existência de uma forma prévia, anterior, de alteridade. Uma alteridade que é constitutiva de toda a identidade. Neste sentido, a possibilidade da poesis humana depende de uma confrontação fundacional com um outro anterior:

"If all human beings and all superpersonal forms of identity arise out of others, this means that there is ultimately only one world. Therefore, on the one hand, we all share a door of entry that opens up an escape route to the situatedness of our condition. This is the door of anterior alterity" (Toren e Pina-Cabral 2009: 14).

Se bem que este mundo não seja necessariamente unitário e seja, por conseguinte, falaciosa qualquer tentativa solipsista de o apreender na sua totalidade pluridimensional, é, no entanto, um mundo comum a todos nós. E, tal como propõe Pina-Cabral, nem a antropologia deverá prescindir de uma noção de real, nem os antropólogos-etnógrafos deverão deixar de insistir na natureza científica do conhecimento antropológico.

Dada a natureza do imponderável, este constitui, na realidade, um princípio de incerteza. Mas, na medida em que a incerteza é geradora de uma intencionalidade, que nunca poderemos captar por completo, dependemos sempre de outrem para fazer sentido dessa intencionalidade, dando assim origem a novas intencionalidades e novos compromissos mútuos de entendimento do mundo. Quer dizer, o conhecimento antropológico só pode produzir-se mediante uma condição de mutualidade. É esta condição que nos permite situarmo-nos por relação ao contexto de observação. A mutualidade é sempre constitutiva do lugar onde o antropólogo se posiciona. No sentido em que a mutualidade implica "estar com", "estar na companhia de", esta condição é, por conseguinte, coconstitutiva do outro, não lhe é nem anterior nem exterior.

Mais ainda, o encontro, o face a face que ocorre na mutualidade implica necessariamente a inscrição de uma ética, isto é, um posicionamento ético no próprio face a face, que é ao mesmo tempo sua condição constituinte. Os dilemas de ordem ética ocorrem por isso sempre no curso do processo da mutualidade e não antes.

Ora, foi mesmo esta condição da mutualidade que me ajudou a pensar sobre a minha posição na relação em campo com psiquiatras e a poder fazer sentido do mundo que partilhei com eles durante o trabalho de campo. 
Por outras palavras, o compromisso mútuo de entendimento do mundo é condição necessária para a produção de conhecimento antropológico e, nesse sentido, constitui também aprendizagem do fazer antropológico. É também sobre essa aprendizagem, que permite produzir conhecimento de tipo científico, que irei agora refletir.

\section{ANATOMIA DOS ESPAÇOS PSIQUIÁTRICOS METROPOLITANOS}

O terreno etnográfico que fui constituindo não resulta de uma qualquer visão "aplanada" ou exterior da realidade. Nem tão-pouco de uma delimitação prévia. O terreno resulta, antes, de muitos imprevistos e da minha experimentação vivencial, por vezes até mesmo sensorial, de inúmeros aspetos, quer conceptuais e arquiteturais, quer institucionais e informais. Uso aqui a categoria "imprevisto" no sentido espacial e metafórico em que um trilho ou caminho não havia sido antecipadamente esperado ou pensado, obrigando-me a explorar o campo em redor na expetativa de encontrar (o melhor) solo para a abertura de trilhos alternativos que me reposicionassem no caminho da indagação inicial. De um modo ou de outro, eles foram-me obrigando a reparar neles, ao mesmo tempo que também assinalavam as estruturas psiquiátricas existentes na cidade.

As etnografias sobre psiquiatria e saúde mental frequentemente elegem para observação e reflexão antropológicas aspetos que, por serem os mais tratados ao longo do tempo, presumimos serem aqueles que diretamente conduzem o etnógrafo ao core do fenómeno psiquiátrico. As etnografias de referência tornam-se deste modo as que se debruçam, por exemplo, sobre as instituições psiquiátricas (Foucault 1991; Goffman 1961), as desordens psiquiátricas (Quintais 2000; Quartilho 2001; Fadiman 1997; Barrett 1996), os hospitais e serviços de psiquiatria (Estroff 1985; Rhodes 1995), a aprendizagem da psiquiatria e da profissão médica (Sinclair 1997; Good e Good 1993; Luhrmann 2000; Bonet 2004) ou os aspetos socioculturais enquanto formatadores ideológicos das nosologias psiquiátricas (Lechner 2009; Incayawar, Wintrob e Bouchard 2009; Martínez-Hernáez 2000).

Por conseguinte, interessada que estava em observar particularmente como os psiquiatras aprendem a sua profissão, pareceu-me inquestionável eleger o seu local de trabalho no hospital como o locus natural dessa aprendizagem. Além disso, a desinstitucionalização dos pacientes psiquiátricos fazia já parte do plano de reestruturação dos serviços de psiquiatria e saúde mental portugueses, iniciado em 2002. Neste contexto, importava-me compreender como os psiquiatras experienciavam um contexto de trabalho que eu entendia como "migratório" e nele aprendiam a sua profissão. Quer dizer, importava-me compreender como os psiquiatras transitavam do hospital psiquiátrico para o hospital geral por referência a esse mesmo contexto de reforma dos serviços de 
saúde mental. Sobretudo, dada esta situação "migratória”, queria compreender como se estabeleciam estas relações de proximidade laboral entre psiquiatras e os seus colegas de outras especialidades, no quotidiano do trabalho no hospital geral.

Os meus primeiros esforços etnográficos concentraram-se então em procurar um serviço de psiquiatria e em obter aí autorização para observar o seu quotidiano. Todavia, inúmeras ocasiões ocorreram em que, tendo obtido prévia autorização por parte de diretores de serviço, ou negociado os termos da minha observação em campo com responsáveis de serviço, me preparava para acompanhar as suas rotinas de trabalho e esse acesso vinha, num derradeiro momento, e de forma imprevista, a ser-me negado pelas mais diversas razões.

Ao mesmo tempo que me indagava sobre a natureza das sucessivas dificuldades que se me deparavam, acabei por percorrer diversos itinerários na área metropolitana de Lisboa, na procura insistente de um outro serviço ou hospital onde pudesse realizar a minha etnografia.

As minhas caminhadas pela cidade em busca desse quase "lugar mítico" - o hospital psiquiátrico - fizeram-me experienciar um campo menos óbvio e arredado das cogitações psiquiátricas mais imediatas. Percorri os itinerários urbanos que me conduziram por entre lugares como os hospitais e centros de saúde, mas também falei com psiquiatras nos seus consultórios particulares. Assisti a congressos de psiquiatria, visitei tendas de divulgação de associações particulares de apoio a doentes, contactei com familiares e amigos de pessoas com doença mental, assisti a eventos de comemoração do Dia Mundial da Saúde Mental. Testemunhei ainda iniciativas no mesmo âmbito, tais como, por exemplo, o Movimento UPA (Movimento Unidos Para Ajudar) - um projeto que reuniu, em 2008, diversas bandas de música portuguesa e realizadores de cinema que produziram e ilustraram, sob a forma de outdoors, inúmeros suportes publicitários numa campanha solidária contra a discriminação das pessoas com doenças mentais.

Na minha demanda pela cidade fui, pouco a pouco, compreendendo que existiam várias "portas" de entrada para o campo psiquiátrico e que este era bem mais complexo do que imaginara. Muitas eram facilmente transponíveis porque abriam para zonas mais obscurecidas, porque menos expostas aos holofotes da vigilância médica institucional. Explorando-as, fui observando que, à semelhança dos campos rurais, existiam certas áreas que se transformavam em zonas de periferia, uma espécie de arrabaldes do campo psiquiátrico. À noite, eu podia encontrar essa periferia sinalizada a cada esquina, a cada ruela mais escura ou sob uma arcada menos iluminada, pelos odores fétidos da urina e de uma outra presença humana que, à luz do dia, tendia a passar-me despercebida, como constatei certa noite em que acompanhei voluntários de uma instituição de apoio aos sem-abrigo na distribuição da refeição noturna. O forte odor a urina sob as arcadas de edifícios da administração pública, 
na baixa lisboeta, nos jardins públicos ou em bairros periféricos, os papelões que serviam de esteira a homens e mulheres enrolados sobre si, em mantas esburacadas e imundas, os sacos de plástico de hipermercados que serviam de termo ao metro quadrado de chão calcetado onde dormiam, tudo adquiria para mim novos significados territoriais simplesmente porque... alguns psiquiatras tinham interpretado o que eu vira, ouvira, cheirara ou tocara, à luz de um quadro de referências psicopatológicas:

- Grande parte dos sem-abrigo da cidade sofre de perturbações mentais. As crises económicas lançam para as bordas da humanidade pessoas que se afundam em depressão séria.

- A desinstitucionalização, por sua vez, envia psicóticos, esquizofrénicos e pessoas com todo o tipo de perturbações mentais para a rua.

- Um indivíduo que sofre de depressão, se não for tratado, aos 55 anos pode ter perdido trinta anos da sua produtividade expectável. Muitos vão parar à rua, sem um teto.

Estas interpretações, sancionadas pelo conhecimento psiquiátrico, alteraram a minha perceção da cidade. Nunca mais passei pelos mesmos locais, à luz do dia, quando os cenários e as pessoas já não eram os mesmos que se veem durante a noite, sem que reconhecesse alguns desses fortes odores que ainda aí permaneciam e os misturasse quer com a minha memória sensorial, quer com as narrativas psiquiátricas sobre os sem-abrigo da cidade. Deste modo, fui descobrindo que a cidade é constituída por zonas marginais cujas dinâmicas, ora centrífugas, ora centrípetas, escapam à nossa visão comprometidamente linear e diurna.

Pouco a pouco, o campo que estudava alargava-se e podia perceber uma outra rede de relações que nunca teria percebido caso tivesse estado ocupada com a minha etnografia dos corredores de um serviço psiquiátrico. Mas o que encontrava na rua não era nem menos importante nem menos "psiquiátrico", na medida em que se constituía por referência a sinaléticas, de vária ordem, da ação psiquiátrica.

Foi deste modo que comecei a olhar para outros espaços na cidade e a descobrir algumas coisas sobre eles. Alguns são espaços apenas transitórios, quer dizer, permanecem fisicamente sinalizados por um dia ou dois para, logo de seguida, desaparecerem, como as tendas de divulgação de organizações de apoios a familiares de pessoas com doença mental, que visitei em outubro de 2009, num parque da cidade.

Numa dessas tendas conversei com as pessoas que distribuíam folhetos informativos sobre uma associação de apoio a doentes com esquizofrenia, conversei com familiares de alguns desses doentes que me contaram os seus próprios percursos até chegarem à organização. Eu própria tivera conhecimento 
dessa iniciativa porque vira um cartaz afixado num serviço de psiquiatria. O que faz um familiar de doente psiquiátrico tomar parte de uma associação de apoio a outros familiares de outros doentes psiquiátricos? A Ana era mãe do Pedro:

"Conheci a associação por intermédio do psiquiatra do meu filho. Ele falou-me nela e que aqui encontraria outras mães e pais que poderiam partilhar as suas experiências, os seus sofrimentos, as suas pequenas alegrias. Às tantas senti-me menos sozinha, menos bizarra. Compreendi que não era a única mãe do mundo a ter um filho esquizofrénico, que havia mundo para além do meu, e um mundo parecido até com o meu. Porque não conhecê-los?"

Compreendi que uma rede invisível e complexa de relações e sociabilidades se produzia a cada instante, num qualquer lugar, assinalando um mundo que existe mesmo para além de nós e que quotidianamente se constitui. Mas só assim o entendi quando conversei com a Ana e a acompanhei nos seus percursos diários durante algum tempo. Como nos lembram os organizadores na introdução do presente dossiê, chamando a atenção para as palavras de Pina-Cabral,

"[p]artindo da constatação de que o mundo vivido é historicamente constituído, os antropólogos foram frequentemente tentados a considerar que o que havia para analisar era apenas esse mesmo processo constitutivo; isto é, que não há mundo (that there is no world)" (Pina-Cabral 2010, cit. em Viegas e Mapril, neste dossiê).

Ora, precisamente, há mundo, há real, e o esforço de descrição produz algum tipo de conhecimento sobre esse mesmo mundo. Recorro agora a dois breves exemplos etnográficos, tentando ilustrar o que quero dizer.

\section{Exemplo 1}

João é enfermeiro psiquiátrico há mais de 50 anos. Começou no Hospital Júlio de Matos no tempo em que vieram os enfermeiros suíços, homens possantes, com grande força de braços. Só eles é que conseguiam conter os loucos em agitação. Não existiam os medicamentos que temos hoje. Hoje a loucura é uma coisa diferente. João contou-me que, quando era ainda um jovem aprendiz de enfermagem, os enfermeiros habitavam na ala dos doentes. Viviam, noite e dia, tal como eles, encerrados na ala psiquiátrica ou numa enfermaria.

João não vivia, contudo, encerrado da mesma maneira. Ele era responsável por uma enfermaria e tinha na sua posse o chaveiro e a chave que encerrava os loucos no lado de dentro. Onde é que estava a chave? "A chave andava sempre connosco, nunca nos separávamos dela. Nós e as chaves eram quem impedia que os loucos transgredissem o seu espaço delimitado". 
Dias depois desta conversa, eu acompanhava João ao longo do corredor do departamento de psiquiatria de um moderno hospital geral, construído na década de 1990, na periferia de Lisboa. Ao longo do corredor, há portas entreabertas por onde se vislumbram acessórios de enfermagem, secretárias, batas brancas penduradas em cabides, pastas e malas de mão pousadas em alguma cadeira. Aproximamo-nos do topo do corredor onde há uma porta encerrada, mesmo defronte de nós. João retira a mão vazia de dentro do bolso da bata e, com a ponta dos dedos, introduz um código num pequeno painel, fixado na parede, ao nível dos olhos.

Cinquenta anos depois, a mão de João encena uma rotina que conhece há décadas: cerra e descerra uma porta que divide e separa os doentes do restante espaço. Já não há uma chave grande que chocalha pendurada num chaveiro preso à cintura do enfermeiro-chefe. Neste outro tempo, há um pequeno painel eletrónico, com um teclado numérico. É preciso estar-se autorizado para ter acesso ao código de abertura desta outra porta deste outro tempo. A mesma mão, a mão do João que aprendeu um dia a girar para a direita e para a esquerda uma peça metálica introduzida num mecanismo de fechadura, também aprendeu a memorizar um código numérico e a teclá-lo num monitor. Mudou o artefacto, mas o gesto é ainda memória do outro: circunscrever, separar, os doentes problemáticos dos restantes ocupantes do serviço.

Como que "adivinhando" os meus pensamentos, João sente necessidade de dizer qualquer coisa. Certamente que interpretou o meu olhar atento, que lhe seguia os gestos da mão:

- Hoje isto é tudo mais moderno - diz, sorrindo em tom de cumplicidade.

- Mas continua a existir uma porta trancada - digo eu, no mesmo tom cúmplice de quem julgou estar a partilhar.

- Pois... - murmura João, no derradeiro momento em que a porta se abre diante de nós, para um outro corredor, e os meus olhos procuram os "outros".

O que acabo de descrever mostra-me que o João me levou a visitar um mundo que ele conhece melhor que eu, e que eu só pude visitar porque ele assim mo permitiu, mas é um mundo que permanece para além de qualquer um dos dois, que de qualquer modo nos é, a ambos, anterior. O João repete os mesmos gestos que muitos antes dele já repetiram também, tal como eu própria repito um modo de olhar que, pelo menos, gerações de antropólogos anteriores a mim já registaram milhares de vezes.

\section{Exemplo 2}

Há espaços que deixam de ser usados e envelhecem, mas não desaparecem totalmente. Continuam sob outras formas. Em 2010 voltei ao primeiro local que visitara quando iniciei o trabalho de campo, quatro anos antes. Aí, no n. ${ }^{\circ} 20$ 
da rua das Taipas, localizava-se o primeiro Centro de Atendimento a Toxicodependentes - o CAT das Taipas. Mas deparei-me com uma porta encerrada. O CAT tinha sido transferido para o novíssimo Parque de Saúde Lisboa Norte. O Parque nascera do encerramento de alguns pavilhões do Hospital Júlio de Matos. Por sua vez, este hospital psiquiátrico ficara muito mais pequeno e o seu funcionamento estava a ser reestruturado à luz das diretrizes da chamada "reforma da saúde mental".

Em setembro de 2010, voltei ao Hospital Miguel Bombarda e muito havia mudado desde que lá entrara pela primeira vez, em 2006. O hospital encerrou definitivamente no final de 2010. A oitava enfermaria e o panótico, cenário de alguns filmes do cinema português contemporâneo, já estão classificados como património de interesse público.

Estes são exemplos de espaços que envelheceram. Em contrapartida há sempre novos espaços a formarem-se continuamente, conquistando outros espaços anteriores. O hospital onde o João começou a trabalhar como enfermeiro, o Júlio de Matos, foi construído, na década de 1940, nos arrabaldes a norte da cidade. Nessa época, com as políticas de obras públicas do Estado Novo, a cidade expandia-se nessa direção (Fernandes 1997). O hospital onde o João hoje trabalha foi construído seis décadas mais tarde, noutros arrabaldes, a ocidente, para lá de uma das portas de entrada na cidade, as portas de Benfica. Sónia, uma das jovens internas de psiquiatria deste mesmo hospital onde o João trabalha, vive num moderno bloco de apartamentos cujos terrenos foram conquistados a baldios e a bairros clandestinos no início de 2000 .

Sónia, diferentemente do João no seu tempo, já não tem de viver dentro do hospital durante o seu internato. Atravessa toda a cidade, num eixo norte-sul, todos os dias, quando sai de casa, de manhã, e depois, quando regressa. Diariamente, de caminho para o hospital, passa para além das portas de Benfica e percorre uma rodovia com um dos tráfegos mais intensos do país - o IC 19 - até, finalmente, chegar, por uma via de acesso exclusiva, ao perímetro do hospital, que serve uma das zonas hoje mais intensamente povoadas do distrito de Lisboa.

O campo de influência psiquiátrica alargou-se geograficamente. Mas também se complexificou infinitamente, pois partilha com outros campos e outras rotas sentidos outros que não exclusivamente os psiquiátricos. Que contributo poderá esta constatação empírica trazer para o debate antropológico sobre como conhecemos o que conhecemos?

\section{A DESCRIÇÃO ETNOGRÁFICA}

As experiências etnográficas de percurso pela cidade podem mesmo contribuir para nos situarmos na teoria social e num posicionamento tal que possa dar conta da complexidade do mundo em que vivemos. Cristiana Bastos (2001) propôs isto mesmo num exercício etnográfico de práticas e representações de 
cura numa rua de Lisboa - a rua de São Lázaro. A microetnografia de curto alcance captou, num vislumbre etnográfico, uma Lisboa contemporânea onde se sobrepõem camadas de sentidos, de tempos e memórias, de espaços diferenciados e combinações de práticas e crenças relativas à saúde, à doença e à cura. O exercício não pretende ser mais que um esboço etnográfico mas, ainda assim, a partir de um pequeno segmento da cidade, a descrição etnográfica densa permite descobrir novas e inesperadas relações que passariam despercebidas caso não passassem pela análise etnográfica, esse clássico e sempre singular método de análise antropológica.

Num outro trabalho etnográfico com objetivos bem distintos dos do exercício de Cristiana Bastos, Luís Vasconcelos, na sua investigação sobre os itinerários do consumo de heroína de jovens consumidores na cidade de Lisboa, descobriu não apenas a realidade constitutiva de uma Lisboa psicotrópica nos relatos destes jovens, que "não eram simples representações da verdade, mas atos de construção cognitiva que servem várias funções" (Vasconcelos 2003: 17), mas também a agencialidade de atores a quem tradicionalmente os poderes relegam para as margens.

As caminhadas que me conduziram através da cidade e dos seus arredores, que me levaram a subir e descer avenidas conhecidas, a fazer de automóvel o percurso para hospitais que se situam junto a eixo rodoviários de intenso fluxo, ou outros que percorri a pé porque a malha apertada das ruas e esquinas dificultava o estacionamento, constituíram emocional e etnograficamente um território psiquiátrico que existe muito para além dos muros dos hospitais psiquiátricos ou das paredes dos serviços de psiquiatria de hospitais gerais ou centros de saúde.

Muito por consequência dos imprevistos no trabalho de campo, pude começar a pensar que a psiquiatria portuguesa e a prática psiquiátrica estão longe de se localizar dentro de fronteiras exclusivamente locais ou até mesmo nacionais. Nesse sentido, apesar de se me terem deparado as maiores dificuldades no acesso ao quotidiano hospitalar strictu senso, presumivelmente em nome da ética dos médicos e suas reticências a que o seu encontro com os pacientes seja presenciado por pessoas estranhas à relação clínica, em contrapartida, pude entender que a ação psiquiátrica não se restringe ao locus da consulta.

A ação psiquiátrica é tão porosa aos efeitos dos fluxos gerados pelas mobilidades quanto qualquer outra atividade. Cada vez mais frequentemente, por exemplo, os jovens internos de psiquiatria constroem novas fronteiras, novos espaços para além dos espaços hospitalares onde aprendem os rudimentos da clínica. Muitos dos jovens psiquiatras que entrevistei participaram em ações de sindicalização face à precariedade laboral e à ausência de contrato coletivo de trabalho; outros falaram-me das suas experiências académicas ou científicas no estrangeiro, para onde foram fazer cursos curriculares ou doutoramentos; outros aspiravam a entrar em redes internacionais de investigação psiquiátrica 
e neurológica. Todos estes percursos são também percursos de sociabilidades várias, ao mesmo tempo que estas sociabilidades ocorrem num mundo contemporâneo, obedecendo igualmente às suas lógicas.

Mas somente a descrição, embora dando conta de um "objeto" multidimensional e permeável aos fluxos e mobilidades da contemporaneidade, pode ficcionar estas fronteiras particulares. Tratar-se-á sempre, porém, de um campo que descobri por causa de sucessivos imprevistos ao longo da investigação. Mas, por efeito desses mesmos imprevistos encontrados, tive também de repensar determinadas categorias de pensamento. É de algumas dessas categorias que irei agora dar conta por meio de exemplos etnográficos, de modo a demonstrar, sob um ângulo diferente do que até aqui tenho estado a seguir, o modo como a minha aprendizagem do trabalho de campo se foi processando e produzindo conhecimento sobre a realidade observada.

\section{COMO NOS TORNAMOS PSIQUIATRAS?}

E COMO NOS TORNAMOS ANTROPÓLOGOS?

\section{O que faz a psiquiatria? Como se é psiquiatra?}

Conheci os meus primeiros informantes psiquiatras através de um colega de doutoramento, que trabalhava no Instituto da Droga e da Toxicodependência e fizera a sua tese de mestrado sobre heroinómanos em Lisboa. Eram quatro psiquiatras e trabalhavam em centros de atendimento a toxicodependentes - os CAT. Foi também com estes psiquiatras que eu decidi que queria fazer trabalho de campo num hospital. Mas isso só aconteceu quando entrevistei o quarto informante, o único que, além do CAT, também trabalhava numa ala de um hospital psiquiátrico. Com eles aprendi que havia muitos psiquiatras que não faziam ideia de como se fazia psiquiatria no hospital porque, simplesmente, o seu próprio trabalho com os toxicodependentes os tinha colocado numa espécie de marginalidade disciplinar, como se fossem uma subespecialidade que não cabia no contexto hospitalar. A Alice, a primeira informante, contou-me um pouco dessa história.

Em fevereiro de 2006 encontrei-me várias vezes com ela no seu gabinete de consultas, no n. ${ }^{\circ} 20$ da rua das Taipas, em Lisboa (CAT das Taipas). Esse era o seu local de trabalho desde que saíra do Hospital de Santa Maria para integrar a equipa das Taipas. Chegar à rua das Taipas partindo do Instituto de Ciências Sociais (ICS), no n. 9 da Avenida Prof. Aníbal de Bettencourt, no Campo Grande, dispondo apenas de um prévio contacto telefónico a marcar a hora do encontro com Alice, constituiu não somente uma primeira exploração do terreno mas igualmente uma primeira experiência da produção de espacialidade desse mesmo terreno.

$\mathrm{Na}$ década de oitenta, os casos de toxicodependência que chegavam às urgências do Hospital Universitário de Santa Maria geravam uma situação 
curiosa. Embora atendidos no serviço de psiquiatria deste hospital, era difícil encará-los nessa altura como doentes de psiquiatria: "Ninguém os queria, ninguém gostava deles. Só davam chatices. Eram utentes de ninguém. Os doentes toxicodependentes são especiais", conta Alice. "Só mais tarde um grupo de psiquiatras veio a formar os CAT, que se desenvolveram de forma autónoma e independente, fora do âmbito hospitalar".

Alice tem memória dos tempos da sua formação médica e dos tempos em que praticou medicina no Hospital Universitário de Santa Maria. A partir do momento em que, por razões profissionais, se dedicou aos CAT, perdeu o contacto profissional com o quotidiano hospitalar e hoje não sabe bem "como é" a psiquiatria hospitalar.

A minha decisão de observar o hospital psiquiátrico chegou depois de me ter encontrado com o quarto "informante" - o Paulo - no Hospital Miguel Bombarda (HMB), onde ele também trabalhava. O facto de ter reunido com ele no seu gabinete, na mais antiga instituição psiquiátrica em Portugal, permitiu-me encontrar um tipo de doentes e de organização dos serviços inteiramente diferente dos que tinha conhecido nos CAT e que me pareceu de imediato ligar-se com o tipo de situações que tinham constituído o meu interesse na tese de mestrado (Patriarca 2002).

Paulo forneceu-me alguns contactos de outros psiquiatras que, como ele, trabalhavam no mesmo hospital. Pensou que me seria útil conversar com pessoas de idades diferentes. E, de facto, pareceu-me, nessa altura, que diferentes gerações teriam diferentes experiências que enriqueceriam a minha etnografia. Os contactos de Paulo tinham-me conduzido a outros espaços e a novas curiosidades. Reparara, por exemplo, que a estruturação do quotidiano ocorria de modo distinto para psiquiatras seniores e para internos da especialidade. Também percebi que ser psiquiatra num hospital como o Miguel Bombarda ou o Júlio de Matos era diferente de ser psiquiatra em hospitais gerais, como o de Santa Maria, o Fernando Fonseca ou o Curry Cabral.

Por isso, os meus esforços concentraram-se, a partir daí, em encontrar maneira de "entrar" no hospital para observar as suas rotinas diárias e fazer a respetiva etnografia. Tratei então de pensar na forma de apresentar o meu interesse particular de investigação aos responsáveis de serviços de psiquiatria, administradores de hospitais, diretores clínicos ou psiquiatras e internos de psiquiatria.

Percebi rapidamente que teria de lidar com a sua expectável curiosidade e explicar-lhes qual o meu contexto académico, qual a minha instituição de acolhimento, quem era o meu orientador, como pensava desenvolver a minha investigação, quais eram as hipóteses que pretendia testar em campo, que autores pensava serem fundamentais para entender a psiquiatria, quais conhecia, se já lera Goffman ou qualquer outro. Pensei que para tudo isto teria de encontrar uma categoria de identificação. Pareceu-me que a categoria "psiquiatras" resolveria razoavelmente o problema. 
Fui, no entanto, confrontada de imediato, e de forma inesperada, com um primeiro problema metodológico. O problema era colocado por parte dos psiquiatras e condicionou a minha entrada, nesse momento, no interior do hospital. O problema que teria de discutir com eles era, precisamente, como eu tencionava estudá-los.

\section{Como classificamos? Como conhecemos o que conhecemos?}

Apresentarei agora uma breve reflexão sobre o meu trabalho de campo que procurará explicitar como, ao tentar explicar a psiquiatras como tencionava estudá-los, redirecionei eu própria a minha reflexão num sentido no qual não tinha antes pensado: como nos classificamos uns aos outros?

Este redirecionamento muito deve ao modo como fui interpelada e como isso me obrigou a indagar sobre a natureza do trabalho etnográfico. A questão prática é saber como representamos o outro. Mas a escrita mostra-nos uma impossibilidade intrigante: não temos acesso a esse outro sem que primeiro esteja nele inscrito um "nós". Esta interpelação, constitutiva de corresponsabilidade (ética), esta mutualidade inscrita no exercício etnográfico, tem sido amplamente debatida por João de Pina-Cabral (2009) nos seus trabalhos mais recentes. E é nesse sentido que a encaro aqui, recorrendo a dois exemplos retirados do meu diário de campo, com os quais procurarei esclarecer um pouco melhor como a imprevisibilidade pode tornar-se produtora de conhecimento antropológico.

Certa tarde, encontrei-me com Eduardo para conversarmos sobre o seu percurso médico como psiquiatra. Eu pensava que, por seu intermédio, surgiria alguma forma de eu ter acesso ao seu local de trabalho. Tínhamos combinado o nosso encontro por telefone. Contei-lhe que fora um primo dele, que eu conhecia por meio de um amigo comum, quem me tinha dado o seu contacto. Expliquei-lhe que estava a fazer um percurso doutoral em antropologia sobre como os psiquiatras se tornam psiquiatras no seu contexto de aprendizagem e de trabalho. Recebeu-me de forma muito simpática em sua casa, um moderno apartamento perto de Lisboa.

Quando entrei ouvi as notas de uma música jazz a tocar na aparelhagem e a voz suave de Billie Holiday. Gosto muito de jazz e, talvez por isso, senti-me algo confortável com o que imaginei ser um traço em comum que facilitaria a desenvoltura da nossa conversa. Talvez até quebrasse um pouco a minha timidez em entrevistar médicos. De alguma maneira não pensada, sentia que ser médico é mais que ser antropólogo. Só mais tarde me questionei sobre este não-pensado. Mas, na altura, este aspeto era suficientemente significativo para determinar, de acordo com o tom da conversa, o rumo e a facilidade ou dificuldade em obter uma maneira de entrar num hospital.

Ao longo de mais de duas horas, Eduardo conversou sobre o seu trabalho, a tese de mestrado que realizara sobre serviços de psiquiatria em articulação com os centros de saúde, as suas rotinas. No final, porém, pronunciou-se 
sobre o que entendia ser a minha impossibilidade de acesso a conhecimento sobre psiquiatras:

“- O que eu the estive a contar sobre a psiquiatria e sobre mim próprio não lhe vai servir para nada no seu estudo.

- Porque não? - indaguei, atónita.

Respondeu-me calmamente:

- Aquilo que você conseguiu ao vir ter comigo foi um enviesamento do seu estudo. Se você quer conhecer os psiquiatras portugueses tem sempre de usar um método que não esteja contaminado, isto é, tem de usar uma amostra recolhida aleatoriamente. É evidente que você chegou aqui porque conhece o meu primo. E se me pede contactos de outros psiquiatras, eu até lhos posso dar, mas vou dar-lhe nomes de colegas de quem gosto, porque acho que são os melhores. Não vou dar-lhe os outros, alguns nem sequer tenho os contactos deles. E isso não vai ser representativo de todos os psiquiatras. Será, quando muito, representativo dos 'psiquiatras que eu lhe escolhi'. Portanto, você vai ter aí no seu estudo um enviesamento grave. Eu não surgi no seu estudo de forma aleatória. Está a contaminar a sua amostra, invalidando-a assim. Percebe?"

O duro remate de uma agradável conversa acabava de me lançar numa angústia que durou meses. Durante muitas semanas, deambulei pelo "meu" terreno, angustiada com o problema da "contaminação" da amostra. Na verdade, essa angústia resultava do conflito entre a minha crença de que aquilo que este psiquiatra me dissera era verdade e o absurdo empírico desta crença. Por um lado, eu tinha de acreditar que o que ele me dissera sobre a metodologia fazia sentido para ele. Por outro, não fazia sentido para a minha própria metodologia. Como compatibilizar este conflito? Como avançar? Desistir da observação que eu delineara parecia-me absurdo. Mas mais absurdo me parecia tentar convencer os psiquiatras de que a minha metodologia era tão válida quanto a deles, sobretudo, quando lhes tinha de dizer que o que eu pretendia era observá-los no exercício do seu trabalho, acompanhando-os nas suas rotinas. Eduardo tinha conseguido, pois, "contaminar-me" com a sua ideia. Mas esta imprevisibilidade da ação de Eduardo, se, por um lado, não me permitia, por meio dele, entrar no hospital onde ele trabalhava, por outro, obrigava-me a procurar um sentido para esta impossibilidade.

Percebi que "fazer etnografia" era entendido como uma metodologia com pouco crédito científico. Para Eduardo, eu parecera-lhe uma má investigadora quando percebera a minha intenção de não usar uma metodologia semelhante à que ele mesmo usaria em circunstâncias idênticas. Como autorizaria então que eu discorresse cientificamente sobre ele, enquanto psiquiatra, e os seus pares? 
Mas o modo como eu me colocava a questão já era intrigante: eu admitia para mim própria que o meu conhecimento sobre outra pessoa dependia, de algum modo, do seu prévio consentimento. Esta questão epistemológica ocupou-me ao longo de todo o trabalho de campo e julgo que a redação da dissertação é uma tentativa de encontrar uma resposta satisfatória para este problema: como conhecemos o que conhecemos? Embora não seja exatamente esta a questão que me ocupa neste artigo, a sua formulação decorreu desta imprevisibilidade de Eduardo.

Esta perturbação teve um efeito prático nos meus contactos seguintes. Daí em diante, sempre que abordava um psiquiatra, comecei a prestar atenção ao modo com que me escutava, geralmente cético, ao explicar-lhe como pretendia realizar a minha etnografia. Passei a ter algum cuidado em não os deixar pensar que o meu intento era estudar "psiquiatras" mas sim observar como aprendiam a ser psiquiatras. Quando lhes perguntava se poderiam ajudar-me a entrar num contexto onde eu pudesse realizar o meu estudo, logo me perguntavam como é que eu ia fazer "isso".

Durante muitas semanas fui apenas assistindo às reuniões clínicas nos serviços de psiquiatria de vários hospitais. Em certo momento, quando eu também queria saber como diagnosticavam as doenças mentais, comecei a perceber que todos os psiquiatras me repetiam uma mesma ideia da representacionalidade. Quando thes perguntava, por exemplo, como o psiquiatra diagnostica as doenças, ou como decide qual a doença de que o paciente sofre, devolviam-me uma expressão de cética condescendência. Olhavam-me como se achassem que jamais eu poderia perceber como eles o faziam, dado que eu não era um deles.

Como poderia então perceber? Para quê darem-se sequer ao trabalho de tentar explicar-me, deixando-me entrar nos seus contextos de trabalho?

Mas então uma outra questão me ocorria: se eu não poderia percebê-los, como poderia descrevê-los? Como se pode compreender algo que não se conhece? Concluí que teria de modificar o ângulo de observação e tentar compreender de outra maneira aquilo que me parecera, durante muitos meses, um exasperante impasse no meu avanço no terreno etnográfico. As implicações metodológicas desta dificuldade eram importantes. Se a proposição que eu tinha vindo a encontrar no terreno era verdadeira, então os psiquiatras nunca poderiam curar os pacientes, pois, nesse caso, teriam também eles de ser os doentes. E esta proposição era mais ou menos absurda. Como construíam então as suas categorias analíticas tendo em vista a terapia?

A questão da intuição, surgida no contexto etnográfico, clarificou um pouco esta outra questão de saber como o psiquiatra constrói as suas categorias analíticas e apontou-me outros interesses de investigação, que procurei seguir. Mas a questão de saber como os psiquiatras constroem categorias analíticas no ato terapêutico colocou-se-me ainda, numa outra perspetiva, quando percebi 
que, nas relações sociais e de amizade que eu ia estabelecendo, também eu era objeto de categorização, mesmo que não estivesse num contexto formal terapêutico. Reparei que sempre que eu dizia que eram eles (os psiquiatras) o meu objeto de estudo, invariavelmente, surgia uma reação que se traduzia, primeiro numa gargalhada (ah, somos nós que somos o objeto de estudo e não os doentes!), logo seguida de uma pergunta que me intimidava, porque encerrava o temível pressuposto de que um psiquiatra está sempre tentando avaliar a nossa sanidade mental. Além disso, este comportamento parecia confirmar o que inúmeras vezes me repetiram, ora sob a forma de advertência, ora sob a forma de irónica cumplicidade: "Os psiquiatras estão habituados a entrevistar. É difícil deixarem-se 'apanhar'. Antes disso, já eles te entrevistaram a ti”.

Invariavelmente, queriam saber: "Por que é que você veio estudar-nos?" Pensando em arranjar uma forma airosa para sair do embaraço classificatório desta pergunta, contei um dia uma meia-verdade. Tinha acabado de ser apresentada, na cantina de um hospital psiquiátrico em Lisboa, ao diretor clínico, e precisava que ele me autorizasse a passear pelo hospital para eu fazer a minha etnografia. Um interno tinha-mo apresentado e recomendara-mo mesmo como a pessoa indicada para o que eu pretendia. No meio de todo o movimento da cantina-bar, sentada a almoçar, diante de um diretor com o prato já esvaziado, na hora tardia do almoço, eu participava contudo do enquadramento psiquiátrico. Pensei em contornar a questão, não respondendo diretamente: "Olhe, o meu primeiro interesse surgiu da literatura. Lembro-me de ter lido O Castelo, do Kafka, teria uns 13 anos..." Ainda eu não tinha terminado e, para minha surpresa e aflição, ele diz-me, enquanto olha distraído para o lado, para um paciente que vai a passar com excessivo vagar, com um tabuleiro cheio de comida: "Ah, sim, O Castelo. Isso é um livro dos obsessivo-compulsivos". E dá-se a gargalhada geral entre os presentes à volta da mesa.

É usual no curso de medicina e nas cadeiras de psiquiatria estudarem-se narrativas literárias como abordagens de casos ou manifestações passíveis de interpretar à luz da epistemologia psiquiátrica. São usadas, por exemplo, pelo valor heurístico que possuem para a aprendizagem do relacionamento do médico com os pacientes e as suas perturbações. Porém, nunca eu tinha pensado em mim própria como tendo uma personalidade obsessivo-compulsiva, mas, vendo bem... como consegue uma adolescente ler até ao fim a história sem história do agrimensor K que chega a um castelo e incessantemente procura, sem nunca o encontrar, o responsável pela sua contratação?

Não contei ao psiquiatra que tinha lido o livro porque o tinha comprado por causa da capa, onde flutuava aéreo um belo castelo germânico. Aos 13 anos, pensava mais ou menos que com tal título e capa só poderia estar diante de uma história de príncipes e princesas encantadas. E depois, ao ler o romance, fora até ao final da história, crescentemente irritada, é certo, mas acreditando que uma história tinha de ter uma história. 
Não contei nada disto ao psiquiatra. Ao mesmo tempo que achei que demoraria uma eternidade a contá-lo, de qualquer modo, ele já fizera o diagnóstico dele: eu era uma obsessivo-compulsiva se o que eu queria era estudar psiquiatras. Talvez até um pouco louca, porque essa era uma tarefa impossível. Olhando agora para o que tinha sido o trabalho de campo até esse momento, talvez ele não estivesse tão longe assim de uma espécie de "verdade".

$\mathrm{E}$, no entanto, se o facto de o psiquiatra não conhecer a minha história não o impedia de me categorizar numa nosologia, e se tal facto não constituíra impedimento para eu lhe reconhecer uma certa verdade, então, a sua ação de me categorizar tinha de significar muito mais do que um mero ato classificatório de desordens psiquiátricas ou até mesmo de "intuição", o que quer que este termo signifique. Se fosse apenas isso, eu teria de assumir a classificação dele como um duplo insulto: a) ele estava a dizer que eu sofria de uma perturbação psiquiátrica; b) fazia-o, para mais, fora do contexto formal da consulta médica.

Da mesma forma, analisar a minha própria reação (a não pensada e a pensada) levou-me a refletir no seguinte. Se eu compreendia que ele não me estava a insultar, isso significava que eu reconhecia qualquer coisa nele, que partilhava com ele uma qualquer semelhança, um reconhecimento de que o que ambos dizíamos fazia sentido. E, se assim era, então, o aparente ato não pensado que o levara à minha categorização, a partir do que lhe contara sobre o livro de Kafka, também teria de ser relacionalmente analisado enquanto fenómeno, e não enquanto ato determinístico de uma qualquer realidade preexistente.

Quer dizer, se analisarmos o ato de classificar em psiquiatria como o fim último do exercício da psiquiatria, estaremos simplesmente a reproduzir um pressuposto da assepsia ontológica (pressuposto, aliás, absurdo) para as desordens psiquiátricas, isto é, que a terapia bem-sucedida depende da capacidade de o psiquiatra conseguir corretamente isolar do mundo a doença, de forma asséptica, como se ela fosse uma coisa-em-si.

Se observarmos a história da psiquiatria, veremos como ela se tem constituído a partir desta mesma crença de que as doenças mentais podem ser conhecidas, alcance-se para tal a técnica científica que permita esse conhecimento. Mas, ao mesmo tempo que esta ideia é incessantemente reproduzida, até mesmo quando se critica o reducionismo biológico da doença mental, o certo é que ela é apenas (mais) um (entre muitos outros) instrumento de mediação usado pelo psiquiatra na sua interpelação. Por si só, estes instrumentos não existem senão numa mediação necessariamente "contaminada". E, por isso, ao serem tocados pelos agentes dessa mediação, estão tão contaminados de sentidos quanto qualquer outra coisa no mundo. 


\section{IMPREVISTOS NA NEGOCIAÇÃO ENTRE AGENTES: O "EMPIRISMO INGLÊS”}

O meu encontro com o diretor clínico lançara-me durante semanas numa espécie de "mal-estar". Duvidava já, quase dois anos depois de ter iniciado o trabalho de campo, que os meus propósitos, que se tinham convertido em urgentes necessidades, dado que o tempo para dedicar ao trabalho de campo se ia encurtando, conseguissem alguma vez interessar suficientemente os responsáveis dos serviços de psiquiatria dos hospitais. Já tinha acumulado algum material etnográfico, que recolhia nos diários, em gravações e entrevistas, leituras de jornais, conforme ia acompanhando as notícias que saíam nos media e iam dando conta de reações, no interior do campo psiquiátrico, à reforma dos serviços em curso.

Em maio de 2007 decidi voltar a falar com Sérgio, psiquiatra no Hospital de Santa Maria. Fora das pessoas mais interessadas em seguir o meu projeto e dera-me algumas ideias que me tinham entusiasmado. Quando fui falar com ele, convidou-me para ir conhecer o Serviço de Urgências daquele gigantesco hospital. Contou-me um pouco da história da construção do edifício, datado dos anos cinquenta.

Sérgio sugeria-me, entusiasmado, que seria muito interessante se eu fizesse aí a minha observação de campo. Teria era de esperar que surgisse um paciente "psiquiátrico". Sérgio dizia-me que era absolutamente fascinante perceber como a equipa de serviço decidia que um caso era "para psiquiatria". Aprenderia muitíssimo naquele lugar, afiançou-me. Teria, no entanto, de pedir autorização ao diretor de serviço, dado que sempre existem constrangimentos de ordem ética que é necessário resolver primeiro. Sentia-me confiante com a sua disponibilidade e interesse. Notei que, enquanto antropóloga, o conhecimento que viesse a produzir naquele contexto seria bem-vindo.

Quando falei com a diretora, ela logo me marcou uma reunião para dias mais tarde. No dia combinado, esperei quatro horas para que me atendesse. Durante esse tempo, fui observando a dinâmica do serviço dos "internamentos", sediado nesse mesmo andar. Até que, finalmente, pudemos conversar sobre o meu projeto e a forma como pretendia realizar a minha etnografia.

Mas, mais uma vez, e de modo para mim não esperado, a diretora ensaiou a minha presença no seu gabinete como um drama de antagonismo disciplinar. Depois de me ouvir, questionou-me sobre a minha formação em antropologia, dando-me a entender que "sabia muito bem" o que era a antropologia. "Não somos "macacos' para antropólogo observar" - disse-me, com autoridade.

Percebi o que queria dizer mas, julgando que seria urgente desfazer o equívoco disciplinar, apressei-me ainda a explicar que eu estava institucionalmente posicionada numa antropologia sociocultural.

"Sei muito bem o que é a antropologia. Os médicos têm cadeiras de antropologia na licenciatura, não é preciso que vocês nos digam o que é a 
antropologia. Eu também li o livro do Jorge Dias sobre aqueles povos de Moçambique, não me lembro agora do nome deles".

Referia-se aos maconde e pareceu-me que esperava que eu soubesse instantaneamente do que ela me falava. Sentia-me a desempenhar o papel de uma aluna submetida à severidade de um exame. Se não respondesse a todas as questões de forma satisfatória, teria de me ir embora. Percebia que o custo para entrar e fazer a minha etnografia dependia da minha capacidade de persuadir o diretor acerca da validade do meu projeto antropológico, algo que a minha examinadora não parecia prestes a conceder. Mas a sua atitude era para mim tão despropositada que resolvi que o meu papel ali não seria o de aluna e, por isso, não fui capaz de lhe responder. Eu estava ali como antropóloga assim esperava ser tratada.

Fui ainda questionada, pelo menos assim me senti, quanto às hipóteses científicas que "trazia" comigo. Outra vez a mesma interrogação, a mesma pergunta que me deixava estarrecida. Apesar da presença do antropólogo em campo ser sempre engajada numa qualquer teoria, não se vai normalmente para o campo para testar hipóteses antecipadamente pensadas. As hipóteses nascem mais tarde, não antes, depois de o antropólogo "experimentar" viver com aqueles que pretende compreender, sendo por eles interpelado, num processo de mútuo entendimento do mundo, para então, sim, poder fazer da investigação uma investigação antropológica.

Este sentido da observação etnográfica não foi de modo algum entendido pela minha interlocutora. As suas interrogações eram por mim interpretadas como juízos de valor. O "meu” método etnográfico não era ali validado porque não era reconhecido. Não existindo reconhecimento, não existia a sua validação científica. A entrada era-me assim recusada por meio da encenação de papéis de desvalorização.

Ofereceu-me um artigo que escrevera sobre psiquiatria e diálogo cultural. Acompanhou-me delicadamente até à porta do seu gabinete, pedindo que lhe trouxesse um projeto escrito para ela apreciar e decidir então se me autorizava a estar no serviço. Inesperadamente, ela disse: "É esse empirismo dos britânicos!..." Lembro-me de ter balbuciado, numa voz sumida: "Não é isso, é que... como é que podemos compreender uma realidade, falar sobre ela, se não estivermos imersos nela, nem que seja por..." “É isso é!", repetiu ela. Sorria, junto à porta. $\mathrm{O}$ empirismo da antropologia britânica!

Confirmei vezes sem conta esta frase escrita nesse dia no meu diário. Anotei a lápis: "Ela sabia, o tempo todo!" Sim, não havia "macacos”. Nunca tinha havido.

Este foi o imprevisto mais duro que encontrei no campo de trabalho, pois por causa dele acreditei que nunca escreveria uma etnografia de um serviço de psiquiatria. Procurei outros "lugares" psiquiátricos para observar. Foi nessas 
caminhadas que acabei por conhecer algumas rotas "psiquiátricas" da cidade. A metáfora dos macacos tinha sido usada pela diretora como uma anedota. Na altura, eu não o tinha percebido e pareceu-me até uma espécie de ácida provocação. Do mesmo modo, a enigmática expressão com que me despediu naquele dia - o "empirismo britânico" - tinha um sentido que ia muito para além do seu significado imediato. Mas só o entendi alguns anos mais tarde.

$\mathrm{Na}$ verdade, o que ela me estava querendo dizer era que se sentiria muito desconfortável se um antropólogo entrasse nos seus domínios. Ela teria então de ceder o seu posicionamento de observador privilegiado a alguém de fora, vendo assim suspenso o seu próprio poder de determinar o que é psiquiátrico e o que não o é. Na sua atitude estava presente o mesmo receio da "contaminação" que eu encontrara em Eduardo e, ao mesmo tempo, o reconhecimento de que não existe mundo fora do mundo e que a ciência, qualquer que seja a sua área de intervenção, é apenas um instrumento operativo.

A escola da antropologia britânica, fortemente enraizada na etnografia, não teme o contacto com as pessoas. É nesse contacto mesmo, nessa inerente mutualidade, que o antropólogo compreende o mundo em que se situa com os seus informantes e que o conhecimento sobre esse mundo se torna possível. O cognitivismo tem impedido que se compreenda este tipo de problema do acesso ao terreno como bloqueios protegidos por interesses, isto é, por categorias valorativas. Nesse sentido, as proposições da diretora que descrevi poderiam ser interpretadas como se tivessem sido apenas uma expressão da autoridade que a ela, enquanto responsável pelo serviço, certamente foi conferida e plenamente reconhecida. Mas o problema, como adverte Donald David, autor que tem servido de inspiração aos nossos antropólogos de referência, como João de Pina-Cabral, reside precisamente em esta perspetiva negar que, simplesmente, coisas como intenções, desejos ou crenças possam residir num lugar que seja no mundo e não na mente:

"As consequências são importantíssimas. Pois se as pessoas podem (habitualmente) exprimir os seus pensamentos corretamente por palavras, então os seus pensamentos - as suas crenças, desejos, intenções, esperanças, expetativas - também têm que em parte ser identificadas por acontecimentos e objetos exteriores à pessoa. Se os significados não estão na cabeça, então, ao que parece, também o não estão as crenças, nem os desejos, nem o resto" (Davidson 2004: 6).

Deste modo, as proposições da diretora, que tantas consequências tiveram no modo como produzi a minha etnografia, têm um alcance bem maior do que a hipotética explicitação de uma (má) vontade. Elas têm que, em parte, ser identificadas por acontecimentos e objetos exteriores ao sujeito que fala 
e age. São esses acontecimentos e objetos exteriores que os nossos pontos de comunicação, de interlocução com os nossos informantes, tocam materialmente. É a partir deles que poderemos tentar compreender um mundo, mesmo que seja impossível compreendê-lo na totalidade.

Julgo que poderia articular aqui muitos trabalhos de campo de antropólogos brasileiros que têm refletido sobre as implicações práticas de questões como a ética, tão comummente levantadas pelos profissionais da medicina como justificação para o seu impedimento ao trabalho de campo de antropólogos no domínio da biomedicina. Os seus trabalhos apontam, no entanto, para um tipo de intervenção ainda pouco explorada etnograficamente em Portugal - de que se fala quando se impõe a ética médica naquilo sobre que queremos falar?

Contudo, a questão ética, quando analisada no trabalho de campo, mostra que esta parece ser uma categoria que poderemos analisar exaustivamente, pois a sua análise abre-nos a porta para que observemos historicamente, mas também materialmente, quer os nossos próprios pressupostos, quer os das pessoas que pretendemos observar. O trabalho de Ceres Víctora mostra-nos precisamente como a questão da ética, que se levantou na observação de um grupo de portadores de VIH, conduziu à reflexão sobre a pesquisa qualitativa e o seu uso na saúde. A partir dessa reflexão, a pesquisadora e suas colaboradoras questionaram as clássicas dicotomias teoria-prática, sujeito-objeto e racionalidade-técnica, identificando essas dicotomias como estando na origem de falácias científicas. Quer dizer, se a presença do pesquisador das ciências humanas pode ser encarada, pela medicina, por exemplo, como "intrusa" e "não-ética" face ao mundo do doente, também, paradoxalmente, a racionalidade médica exclui esse mesmo mundo, importando-lhe apenas a doença e os seus sinais. Mas os antropólogos brasileiros vão mais longe ainda na extração das implicações éticas e epistemológicas e observam que "esses questionamentos, quando projetados para os Comitês de Ética em Pesquisa, apresentam o grande desafio de avaliar a adequação metodológica em conjunto com os procedimentos éticos de cada projeto", quer este seja um projeto individual quer seja um projeto levado a cabo por instâncias governativas ou não-governativas (Víctora 2011: 111). Estes antropólogos trazem para a arena da discussão a questão política da saúde pública (Langdon, Maluf e Tornquist 2008), ao mesmo tempo que apresentam o grande desafio de questionar, problematizando-a, a noção ocidental de "indivíduo", recorrente na medicina ocidental em detrimento da noção de pessoa, como bem reflete Luiz Fernando Duarte a propósito da sua pesquisa de campo em Niterói, observando as classes trabalhadoras e a construção das suas identidades sociais (Duarte 1988, 2003, 2004a). 


\section{CONCLUSÃO}

A etnografia que escrevi foi o relato do meu quotidiano num campo que não é menos "psiquiátrico" que um qualquer outro quotidiano de um serviço de psiquiatria que eu pudesse ter registado no meu diário de campo. Só muito mais tarde, perante a insistência desesperada do meu orientador para que começasse a escrever sobre os meus longos meses em campo, comecei a compreender que, a existir um centro, ele será necessariamente um centro etnograficamente imaginado. Mas o corpo do etnógrafo, esse, sentiu as suas pressões, os efeitos das suas forças, não só centrípetas mas, sobretudo, as centrífugas. A atenção aos efeitos dessas forças na escrita etnográfica ajudou-me a posicionar-me na interpelação dos psiquiatras ao meu trabalho e à minha presença no seu campo. Procurando trilhos e caminhos em torno do hospital que me conduzissem à porta de entrada seguinte, encontrei não um serviço de psiquiatria, mas um campo psiquiátrico: mais, um terreno metropolitano, mundo bem mais vasto do que aquele que inicialmente imaginara. Essa foi a minha primeira aprendizagem resultante destas múltiplas interpelações em campo.

Os sucessivos imprevistos de que aqui fui dando conta resultaram, na maior parte, em descobertas. Se bem que aqui tenha descrito os imprevistos com que me defrontei ao longo do trabalho de campo como impedimentos inesperados relativamente a uma entrada cuja autorização, tudo indicava na altura, me seria concedida sem problemas de maior, na verdade, as implicações teóricas e epistemológicas resultantes desses impedimentos foram bem mais importantes do que podia previamente supor. Por meio delas, refiz muitas das categorias que levava inicialmente para o campo: como proceder metodologicamente, como classificar, compreender e representar o outro e a mim própria, como negociar categorias de conhecimento?

A cidade foi surgindo aos meus olhos de modo diferente. Avistei-lhe outras paisagens (espaciais e temporais), toquei nas texturas de arquiteturas nem sempre visíveis ao olhar demasiado familiarizado do etnógrafo em casa. A questão da racionalidade como marca de modernidade não podia deixar de ser contemplada na minha etnografia. Mas não consegui dissociar essa marca como um traçado arquitetural de algo bem mais estruturante, não só da psiquiatria, mas também da antropologia, e de nós todos que habitamos um mundo comum. Talvez só me tenha verdadeiramente ocorrido explorar essas texturas nas dinâmicas da cidade depois de ter entendido esta, não como uma planura, um cenário, mas antes como um processo temporal e espacialmente interativo com os sentidos, as memórias, a aprendizagem e experiência, e com aqueles cujas vidas queria conhecer.

Olhando um pouco para esse tempo, reconheço que a minha noção de "centro" me conferia nessa altura uma aparente legitimidade para o encarar enquanto core, isto é, como ponto de confluência de forças a partir das 
quais emanava o que quer que fosse que conglomerasse aquilo que eu entendia como "sentido-ele-mesmo" da prática psiquiátrica, ainda que não tivesse sequer questionado a priori esse sentido. Tendo como inspiração as etnografias sobre o quotidiano dos serviços de psiquiatria que encontrara em monografias tão exemplares como as de Sue Estroff (1985), Lorna Rhodes (1995), Rob Barrett (1996) ou Tanya Luhrmann (2000), também eu ambicionava alcançar um horizonte longínquo, à maneira de Malinowski, isto é, encontrar a entrada definitiva para a observação daquilo que julgava ser o motor de produção do sentido psiquiátrico - o quotidiano no serviço de psiquiatria lisboeta -, ainda que inicialmente também não me tivesse questionado sobre a razão de ser de todos os autores destas etnografias fazerem parte, de um modo ou de outro, do círculo das mesmas familiaridades psiquiátricas que intentavam estudar.

Rob Barrett, por exemplo, é simultaneamente psiquiatra e antropólogo, o que facilitou o seu estudo da esquizofrenia num hospital psiquiátrico australiano, onde pôde acompanhar o trabalho de uma equipa psiquiátrica. Tanya Luhrmann, que diz de si própria ser meio-antropóloga (a halfie anthropologist) por o seu pai ser psiquiatra e ela própria ter ponderado seguir psiquiatria, frequentava um curso semestral onde acompanhava o treino de internos de psiquiatria. O seu intuito não era escrever uma etnografia mas, sim, aprender algo sobre psicoses e depressões e sobre o modo como funcionava a psicanálise. O objetivo era o de tentar perceber se as doenças psiquiátricas que ela vira em San Diego eram iguais no Tibete ou no Bornéu - lugares, como ela diz, onde ninguém ouvira falar de Freud. Um dia, muito naturalmente, um desses jovens internos perguntou-lhe o que ela achava de escrever sobre eles, psiquiatras. Outros autores cujo trabalho antropológico no âmbito da psiquiatria produziu referências importantes, como Kleinman (1988), Good e Good (1993), Young (1990) ou Incayawar, Wintrob e Bouchard (2009), são antropólogos e psiquiatras e têm usado a sua formação secundária em antropologia para refletir sobre a sua própria profissão enquanto psiquiatras.

Referindo-se à importância da familiaridade prévia com o campo estudado, Luís Vasconcelos chama a atenção para a utilidade de o etnógrafo não ser totalmente estranho ao campo para que lhe possa ser reconhecido, e até facilitado, o acesso:

"Muito do meu interesse pelos toxicodependentes radica no facto de ser funcionário do Serviço de Prevenção e Tratamento da Toxicodependência, hoje Instituto da Droga e da Toxicodependência, e de durante quase seis anos, com início em 1988, menos de um ano decorrido sobre a sua inauguração, ter trabalhado no CAT das Taipas. Muito da facilidade com que foi autorizada a realização do trabalho de campo deve-se a esta situação. Não foi certamente a apresentação a alguns utentes desta instituição como 
antropólogo interessado em consumidores de heroína, facto que me atribui uma relativa exterioridade em relação às profissões dos vários trabalhadores deste CAT, que deixou de denunciar a familiaridade com os espaços onde tal apresentação foi efetuada. Aceitei mesmo a sugestão, feita por alguns dos meus antigos colegas de trabalho, para conversar com alguns dos utentes apresentados. Foi nessas conversas que Rui e Inês aceitaram ser entrevistados" (Vasconcelos 2003: 16).

No meu caso, a minha familiaridade com o terreno psiquiátrico resumia-se à minha anterior experiência de investigação, no âmbito da minha dissertação de mestrado em Ciências Sociais, sobre a desinstitucionalização num programa de reabilitação na Casa de Saúde do Telhal (Patriarca 2002). Como é sabido, o acesso aos terrenos de investigação constitui uma parte importante, e até determinante, do rumo que essa mesma investigação poderá ter. Quanto mais rapidamente e sem grandes sobressaltos burocráticos o etnógrafo encontrar um contexto de observação, tanto menos possibilidades haverá de ver comprometidos os seus esforços de entrada no campo que pretende observar. Mas nem sempre lhe é permitido que decida os termos da sua observação sem uma qualquer contrapartida ou negociação prévias. Outras vezes, o acesso é-lhe simplesmente barrado em alguma instância intermédia ou superior, e aquele pode ver o seu trabalho comprometido total ou parcialmente, como nos mostram as reflexões de antropólogos como Piero Leirner $(1997,2008)$ ou Frank Pieke (2000).

Finalmente, como se faz então etnografia, como nos tornamos antropólogos através dessa aprendizagem do trabalho de campo?

Um dos primeiros ensaios de resposta a esta questão fê-lo Evans-Pritchard num pequeno texto de reflexão sobre o seu próprio trabalho de campo. Nesse mesmo texto, que apelidou de fragmentos de história antropológica, Evans-Pritchard remeteu uma possível resposta para a enigmática afirmação de Paul Radin, antropólogo de origem austro-americana: "Nunca ninguém sabe inteiramente" (Evans-Pritchard 1976: 240). O quase aforismo de Radin, que estudou com Franz Boas e influenciou gerações de antropólogos americanos, embora não respondesse de imediato à inquietação dos inúmeros alunos e leitores de Evans-Pritchard - como se faz trabalho de campo? -, servia, no entanto, a este último, de mote às suas reflexões, tratando de mostrar o quanto o princípio da incerteza era metodologicamente fundador do trabalho de campo. Era assim, deste modo, convocado para o "fazer antropológico" o empirismo implicado na aprendizagem de "ser etnógrafo". Tratava-se de não mais que uma atualização da noção malinowskiana da imponderabilia da vida social (Malinowski 1997 [1961]), isto é, de tudo aquilo que para Malinowski parecia desviar-se da "evidência concreta" observada pelo etnógrafo (Dias 1997: 42). 
Todavia, se a natureza epistemológica da incerteza se impõe na antropologia clássica enquanto estratégia de conhecimento sobre os indivíduos e sociedades estudadas, relativamente aos quais o etnógrafo se mantém num aparente posicionamento de distanciação, quer geográfica, quer sociocultural, já nos finais do século XX é precisamente a ideia de distanciamento como neutralidade que é posta em causa pela crítica antropológica. Doravante, não mais se poderá ignorar que a presença do etnógrafo é sempre ideologicamente pensada e que tal condição acarreta importantes implicações éticas, teóricas e epistemológicas.

Numa avaliação do gesto fundador de Malinowski, apresentada num volume dedicado ao trabalho de campo dos tempos modernos, Jill Dias sugeria que foi

"precisamente o crescente reconhecimento da necessidade de revisão das categorias e aceções culturais, não só dos indivíduos estudados pela etnografia mas também do próprio etnógrafo, que levou a nova antropologia interpretativa a refletir mais profundamente sobre o trabalho de campo etnográfico como fonte de conhecimento" (Dias 1997: 50).

Na década de noventa, tornava-se cada vez mais insustentável a visão "panótica" implícita na conceção malinowskiana do observador-participante. Ao mesmo tempo que o enfoque do etnógrafo se virava para a processualidade do fazer etnográfico, comanufaturava-se no mesmo gesto os meios da aprendizagem dos múltiplos afazeres do trabalho de campo, entre eles, a aprendizagem de como integrar as interpelações com que aquele se confronta na rotina do exercício antropológico.

Muito desta revisão se deve às profundas alterações na conceção das fronteiras geográficas e físicas dos terrenos estudados, bem como às "descobertas" etnográficas das suas margens e forças hegemónicas. Mas também muito se deve aos deslocamentos desses terrenos para o at home do etnógrafo, como tem sido discutido por Pina-Cabral (1992, 2000, 2006), Lima e Sarró (2006) ou Mapril $(2006,2008)$ em ensaios dedicados à reflexão antropológica sobre a condição dos terrenos metropolitanos contemporâneos.

A leitura desses textos não pode deixar de nos mostrar a relevância das forças dinâmicas que permanentemente produzem os movimentos tectónicos que sentimos sob os terrenos que habitamos. E, se distanciarmos o nosso olhar para horizontes geográficos aparentemente tão distantes como o Brasil ou a China, certamente encontraremos etnografias que nos mostram como as dificuldades relatadas obrigaram a que o antropólogo encontrasse caminhos distintos que, não somente não se tornaram menos científicos, como também produziram conhecimento sobre o mundo. Veja-se, a título de exemplo, trabalhos de estudantes de pós-graduação brasileiros, como os de Piero Leirner 
(2008), que lhe viu serem sucessivamente indeferidas as autorizações para observar elites militares, ou os de Rui Harayana (2008), sobre as dificuldades que lhe foram impostas, em nome da ética médica, por uma equipa de investigação biomédica quando este antropólogo procurava observar o trabalho dessa mesma equipa.

E, contudo, encontramos relatos semelhantes por parte de antropólogos de renome internacional, como nos mostra, por exemplo, Frank Pieke a propósito das suas reflexões sobre o trabalho de campo que realizou na China (Pieke 2000), ou João de Pina-Cabral (2002) sobre o trabalho que realizou em Macau sobre as elites governativas, ou ainda trabalhos de importantes pesquisadores brasileiros sobre o campo da saúde e da medicina, como nos mostram as reflexões de Ceres Víctora (2011) ou Duarte (2003, 2004a, 2004b). Estes relatos mostram-nos que, mesmo geograficamente distantes, os problemas epistemológicos colocados no trabalho de campo são semelhantes aos que encontramos at home, na medida em que as relações de poder com as elites ditam elas próprias que encontremos outros caminhos e que reflitamos sobre as suas implicações na produção de conhecimento antropológico.

O horizonte distante desloca-se em direção à proximidade e impõe novas incertezas, sob a forma de novos imprevistos, que constituem, por sua vez, novas condições de produção do conhecimento, como bem o demonstra ainda Antónia Pedroso de Lima (1997) a propósito do seu trabalho sobre as grandes famílias das elites financeiras de Lisboa. No seu conjunto, todas estas etnografias nos mostram que, para constituirmos os nossos terrenos, temos também de os entender como uma arena pública, onde o consentimento, a ética e a negociação, em jogo contínuo, são aspetos com que cada vez mais teremos de aprender a lidar. As relações de poder que se estabelecem com a nossa presença tenderão a ser tão mais conflituais quanto mais nos aproximarmos das elites de que queremos produzir conhecimento antropológico. 


\section{BIBLIOGRAFIA}

BARRETT, Rob, 1996, The Psychiatric Team and the Social Definition of Schizophrenia: An Anthropological Study of Person and Illness. Cambridge, Cambridge University Press.

BASTOS, Cristiana, 2001, "Omulu em Lisboa: etnografias para uma teoria da globalização", Etnográfica, V (2): 303-324.

BONET, Octávio, 2004, Saber e Sentir: Uma Etnografia da Aprendizagem da Biomedicina. Rio de Janeiro, Editora Fiocruz.

DAVIDSON, Donald, 2004, "Conhecer a própria mente", Crítica, 24 de setembro, online em < http://www.criticanarede.com>, trad. de Luís Augusto, sob autorização de Marcia Cavell, detentora dos direitos de autor de Donald Davidson.

DIAS, Jill R., 1997, "Entre arte e ciência ou o etnógrafo como herói romântico: Malinowski e o trabalho de campo antropológico", Ethnologia, n. s., 6-8: 39-53.

DUARTE, Luiz Fernando, 1988, Da Vida Nervosa das Classes Trabalhadoras. Rio de Janeiro, Jorge Zahar Editor.

DUARTE, Luiz Fernando, 2003, "Indivíduo e pessoa na experiência da saúde e da doença", Ciência e Saúde Coletiva, 8 (1): 173-183.

DUARTE, Luiz Fernando, 2004a, "Ética em pesquisa e 'correção política' em antropologia”, em Ceres Víctora, Ruben Oliven, Maria Eunice Maciel e Ari Pedro Oro (orgs.), Antropologia e Ética: O Debate Atual no Brasil. Niterói, Edições da UFF, 125-130.

DUARTE, Luiz Fernando, 2004b, "A pulsão romântica e as ciências humanas do ocidente", Revista Brasileira de Ciências Sociais, 19 (55): 5-18.

ESTROFF, Sue, 1985, Making It Crazy: An Ethnography of Psychiatric Clients in an American Community. Berkeley e Los Angeles, University of California Press.

EVANS-PRITCHARD, E.E., 1976, "Some reminiscences and reflections on fieldwork", apêndice de Witchcraft, Oracles and Magic among the Azande. Oxford, Clandendon Press, 240-254 .

FADIMAN, Anne, 1997, The Spirit Catches You and You Fall Down: A Hmong Child, Her American Doctors, and the Collision of Two Cultures. Nova Iorque, Farrar, Strauss and Giroux.

FERNANDES, José Manuel, 1997, Lisboa em Obra(s). Lisboa, Livros Horizonte.

FOUCAUlT, Michel, 1991, Discipline and Punish: The Birth of the Prison. Harmondsworth, Penguin Books.

GOFFMAN, Erving, 1961, Asylums: Essays on the Social Situation of Mental Patients and Other Inmates. Londres, Anchor Books.

GOOD, Byron, e Mary-Jo DelVecchio GOOD, 1993, "Learning medicine: the constructing of medical knowledge at Havard Medical School", em Margaret Lock e Shirley Lindenbaum (orgs.), Knowledge, Power and Practice: The Anthropology of Medicine and Everyday Life. Berkeley, University of California Press, 81-107.

HARAYANA, Rui Massato, 2008, "O “ético’ êmico ou o que é uma boa pesquisa biomédica”, comunicação apresentada na 26. ' Reunião Brasileira de Antropologia, Porto Seguro, Baía.

INCAYAWAR, Mario, Ronald WINTROB, e Lise BOUCHARD (orgs.), 2009, Psychiatrists and Traditional Healers: Unwitting Partners in Global Mental Health. Oxford, Wiley-Blackwell.

KLEINMAN, Arthur, 1988, Rethinking Psychiatry: From Cultural Category to Personal Experience. Nova Iorque, Free Press. 
LANGDON, Ester, Sonia MALUF, e Susana TORNQUIST, 2008, “Ética e política na pesquisa: os métodos qualitativos e seus resultados”, em Iara Guerriero, Luísa Schmidt e Fábio Ziecker (orgs.), Ética nas Pesquisas em Ciências Humanas e Sociais na Saúde. São Paulo, Aderaldo e Rothschild Editores, 128-147.

LECHNER, Elsa (org.), 2009, Migração, Saúde e Diversidade Cultural. Lisboa, Imprensa de Ciências Sociais.

LEIRNER, Piero, 1997, Meia-Volta Volver: Um Estudo Antropológico sobre a Hierarquia Militar. Rio de Janeiro, Fundação Getulio Vargas.

LEIRNER, Piero, 2008, A Etnografia como Extensão da Guerra por Outros Meios: Notas sobre a Pesquisa com Militares Brasileiros, apresentado numa aula, no Instituto de Ciências Sociais, Lisboa, no âmbito de uma pesquisa de pós-doutoramento.

LIMA, Antónia Pedroso de, 1997, "Trabalho de campo com famílias da elite empresarial de Lisboa: um terreno para a análise e o exercício de relações de poder", Ethnologia, n.s., 6-8: 105-122.

LIMA, Antónia Pedroso de, e Ramon SARRÓ (orgs.), 2006, Terrenos Metropolitanos: Ensaios sobre Produção Etnográfica. Lisboa, Imprensa de Ciências Sociais.

Luhrmann, T.M., 2000, Of Two Minds: The Growing Disorder in American Psychiatry. Londres, Picador.

MALINOWSKI, Bronislaw, 1997 [1961], "Introdução a Os Argonautas do Pacífico Ocidental", em Ethnologia, n. s., 6-8: 17-38, trad. Ana Paula Dores.

MAPRIL, José, 2006, "Passageiros de Schengen: a dialética entre fluxo e encerramento no trabalho de campo", em Antónia Pedroso de Lima e Ramon Sarró (orgs.), Terrenos Metropolitanos: Ensaios sobre Produção Etnográfica. Lisboa, Imprensa de Ciências Sociais, 53-71.

MAPRIL, José, 2008, A “Modernidade” do Sacrifício: Qurban, Lugares e Circuitos Transnacionais entre Bangladeshis em Lisboa. Lisboa, ICS-UL, tese de doutoramento.

MARTÍNEZ-HERNÁEZ, Angel, 2000, What's Behind the Symptom? On Psychiatric Observation and Anthropological Understanding. Londres e Nova Iorque, Routledge.

PATRIARCA, Madalena Rolim, 2002, A Desinstitucionalização e a Humanização em Saúde Mental: Uma Reflexão Antropológica, Lisboa, Instituto de Ciências Sociais da Universidade de Lisboa, tese de mestrado em Ciências Sociais.

PIEKE, Frank, 2000, "Serendipity: reflections on fieldwork in China", em David Parkin, Paul Dresch e Wendy James, Anthropologists in a Wider World. Oxford, Berghahn Books, 129-150.

PINA-CABRAL, João de, 1992, Os Contextos da Antropologia. Lisboa, Difel.

PINA-CABRAL, João de, 2000, "A difusão do limiar: margens, hegemonias e contradições", Análise Social, XXXIV (153): 865-892.

PINA-CABRAL, João de, 2002, Between China and Europe: Person, Culture and Emotion in Macao. Londres e Nova Iorque, Berg Publishers.

PINA-CABRAL, João de, 2006, "Reflexões finais", em Antónia Pedroso de Lima e Ramon Sarró (orgs.), Terrenos Metropolitanos: Ensaios sobre Produção Etnográfica. Lisboa, Imprensa Ciências Sociais, 177-192.

PINA-CABRAL, João de, 2009, "A prece revisitada: comemorando a obra inacabada de Marcel Mauss", Religião e Sociedade, 29 (2): 13-28.

QUARTILHO, Manuel, 2001, Cultura, Medicina e Psiquiatria. Coimbra, Quarteto.

QUINTAIS, Luís, 2000, As Guerras Coloniais e a Invenção da História. Lisboa, Imprensa de Ciências Sociais. 
RHODES, Lorna, 1995, Emptying Beds: The Work of an Emergency Psychiatric Unit. Berkeley e Los Angeles, University of California Press.

SINCLAIR, Simon, 1997, Making Doctors: An Institutional Aprenticeship. Oxford e Nova Iorque, Berg.

TOREN, Christina, e João de PINA-CABRAL, 2009, "Introduction: what is happening to epistemology?", Social Analysis, 53 (2): 1-18.

VASCONCELOS, Luís, 2003, Heroína: Lisboa como Território Psicotrópico nos Anos Noventa. Lisboa, Imprensa de Ciências Sociais.

VÍCTORA, Ceres Gomes, 2011, "Uma ciência replicante: a ausência da reflexão sobre o método, a ética e o discurso". Saúde e Sociedade, 20: 104-1 12.

YOUNG, Allan, 1990, "Moral conflicts in a psychiatric hospital treating combat-related post-traumatic stress-disorder (PTSD)”, em G. Weisz (org.), Social Science Perspectives on Medical Ethics. Dordrecht, Kluver Academic Publisher, 65-82. 